\title{
MODEL OF STUDENTS' SPORT-ORIENTED PHYSICAL EDUCATION WITH APPLICATION OF INFORMATION TECHNOLOGIES
}

Olkhovy O.M., Petrenko Y.M., Temchenko V.A., Timchenko A.N. Kharkov National University

\begin{abstract}
Purpose: working out and practical application of approaches to perfection of physical education system's functioning. Material: in the research students (boys $-\mathrm{n}=92$, girls $-\mathrm{n}=45$ ) of 18-20 years old took part. Results: structural model of students' sport-oriented physical education with application of information technologies has been formed. The main purpose of such model's creation was cultivation of students' demand in physical functioning and formation of healthy life style in students' environment. The model of the process includes orienting, executive and control components. In this model groups of commonly accepted physical education and sport-oriented groups function. Conclusions: Main structural components of the created model have been determined: conceptual, motivation-active, resulting.
\end{abstract}

Key words: model, students, sport-oriented physical education, structure, information technologies.

\section{Introduction}

Recent years there has been observed substantial worsening of students' health and physical condition [22, 23, 26, 27, 32-34]. Most scientists connect this fact with unfavorable social economic life conditions and ecology as well as with significant reduction of students' interest to physical culture and sports, reduction of effectiveness of physical education (PE) system in higher educational establishments (HEE) [2, 12, 14, 20, 38-42]. Application of traditional approaches does not influence on students properly as well as influence on their strive for sport practicing, for constant self-perfection and physical functioning $[1,16]$. Re-organization of PE in Ukrainian HEEs requires searching of new approaches to health related physical culture work with students [7, 8, 13, 19].

Analysis of researches and publications showed that nowadays in students' PE sport-oriented technologies are implemented more and more intensively. It facilitates increase of students' interest to physical culture in HEE's educational space $[1,10,11]$. Implementation of sport-oriented technologies in students' PE results in stage-by-stage increasing of physical culture classes' attendance, interest to chosen kind of sport, rising of motor functioning's level in class and out of class time $[17,18,20]$.

In present conditions tendencies of education development imply transition of control over educational process to new technological level, envisaging application of information technologies [8, 21]. Such approach is a necessary condition of increasing of education's quality [7, 9, 13, 24, 25, 28-31]. However, at present there is no single approach to organization of students' sport-oriented physical education (SOPE) with application of information technologies (IT) influence of IT application both on organization and on effectiveness of SOPE functioning has been studied insufficiently $[10,21]$.

\section{Purpose, tasks of the work, material and methods}

The purpose of the research: is formation of SOPE with application of IT for perfection of PE system in HEE. Material: students of Kharkov national university (KNU), named after V.N. Karazine (boys-n=92, girls- n=45) of 18-20 years old took part. Methods of the research: theoretical analysis of scientific literature, simulation, forming pedagogic experiment.

\section{Results of the research}

Transition of discipline "Physical culture" to optional level (which is not included in curriculum and does not have final control) in Ukrainian HEEs requires change of approach to content of all learning process in present conditions of organization of higher education. Involvement of students in learning process becomes the main factor, determining functioning of PE departments in HEEs structure. For improving of physical fitness results and rising of students' psychophysiological condition it is necessary to seek principally new approaches, methodic and technologies, which would comply with individual features, maximally facilitate effective realization of interests, demands and bents of students [7, $11,12,35-37,43,44]$.

(c) Olkhovy O.M., Petrenko Y.M., Temchenko V.A., Timchenko A.N., 2015 http://dx.doi.org/10.15561/20755279.2015.0304 
Working out of SOPE model, based on students' motivation for PE trainings 12, 14, 15] provides opportunities to wider regard the tasks of such training process, to use specialists, assess quality of work of different links of education and to build model as a standard. Basing on such standard it would be possible to systemize and organize PE training process in HEE.

Let us formulate clearer the features of SOPE model, starting from conceptual principles of learning process. In this case PE training process will be provided with adaptive applied model, adequate in respect to object of the research, considering possible changes. The purpose of SOPE concept is presentation of theory in instructive and applied form. The most accessible is idea, based on achievement of useful final result - formation of healthy life style in students' environment. Criterion of such concept's substantiation is practicability of its application in HEEs. It will permit to determine disadvantages of existing in HEEs at present PE system [3-5, 12, 13, 16, 21, 23].

One of main ways of differentiated approach's and PE wholeness's realization in process of construction of SOPE model was approach, in compliance with which the following requirements to content of pedagogic model were put: didactic character (purposefulness, significance of training's content, dynamic character of its development, rationality of model's construction); methodic character (presence of logic and structure in reflecting of content; correspondence of scope of information to conditions of optimal functioning); connection of content with algorithm of the conducted measures; technical character (varying of information rendering temp, up-to date character of means of content's reflection, convenience of control over conducted measures) $[13,16,19]$. Content of training process shall be reflected in model systemically, with clearly outlined logic, special techniques and parts, Such approach attracts students' attention and causes positive emotions. With it, model of training process's content shall include orienting, executive and control components.

Orienting component contains main conceptual idea of training content and main positions of training. In this component program of actions' fulfillment is reflected, which ensures more efficient approach to students' mastering of training content and facilitates formation of their certain readiness to further professional functioning. Orienting component determines purpose, tasks, principles and sequence of appropriate actions of training.

Executive component is the main in the model. Its content is presented as organizational measures and conditions. They ensure effective course of realization of this content, methodic and technologies of organization of training process. It shows the ways of solution of the researched problem.

Control component is intended for determination of effectiveness of the created model, degree of correspondence of all changes in training variant of previous type. With its help required correction of orienting and executive components can be done.

It is purposeful to apply these conceptual approaches when using IT with introduction of all mentioned components and a number of changes in structure of commonly accepted in HEEs SOPE model. Main purpose of IT application in SOPE was cultivation of students' demand in physical functioning, rising of PE functioning in HEEs. As final result it is formation of student's healthy life style.

Conceptual tasks of SOPE with application of IT in HEE were the following:

- increasing of students' motivation for physical trainings with active usage of IT for this purpose (system of HEE's, physical education department's, sport clubs', organs of students self governing sites and etc.);

- increasing of effectiveness of general physical, technical and theoretical fitness of students in chosen kind of sports (motor functioning) with the help of IT for visualizing of training process.

Combination of correspondence of purpose and tasks, following the SOPE principles, simultaneity and complexity of their application, efficiency, create own orientation in compliance with conditions and specificities of sport orientation [22].

By the results of the conducted theoretical analysis of scientific sources [1, 9-11, 16-23, 46-49], considering basic principles of theory of physical education and sports (L.P. Matveyev, 1991; V.M. Platonov, 2004-2014; T.YU. Krutsevich, 2008-2014; Zaporozhanov V.A., 2009-2015) ad results of practical researches of PE departments of different HEEs, devoted to IT application in training process of students we optimized SOPE model. The model contains main structural components, shown in fig.1: 


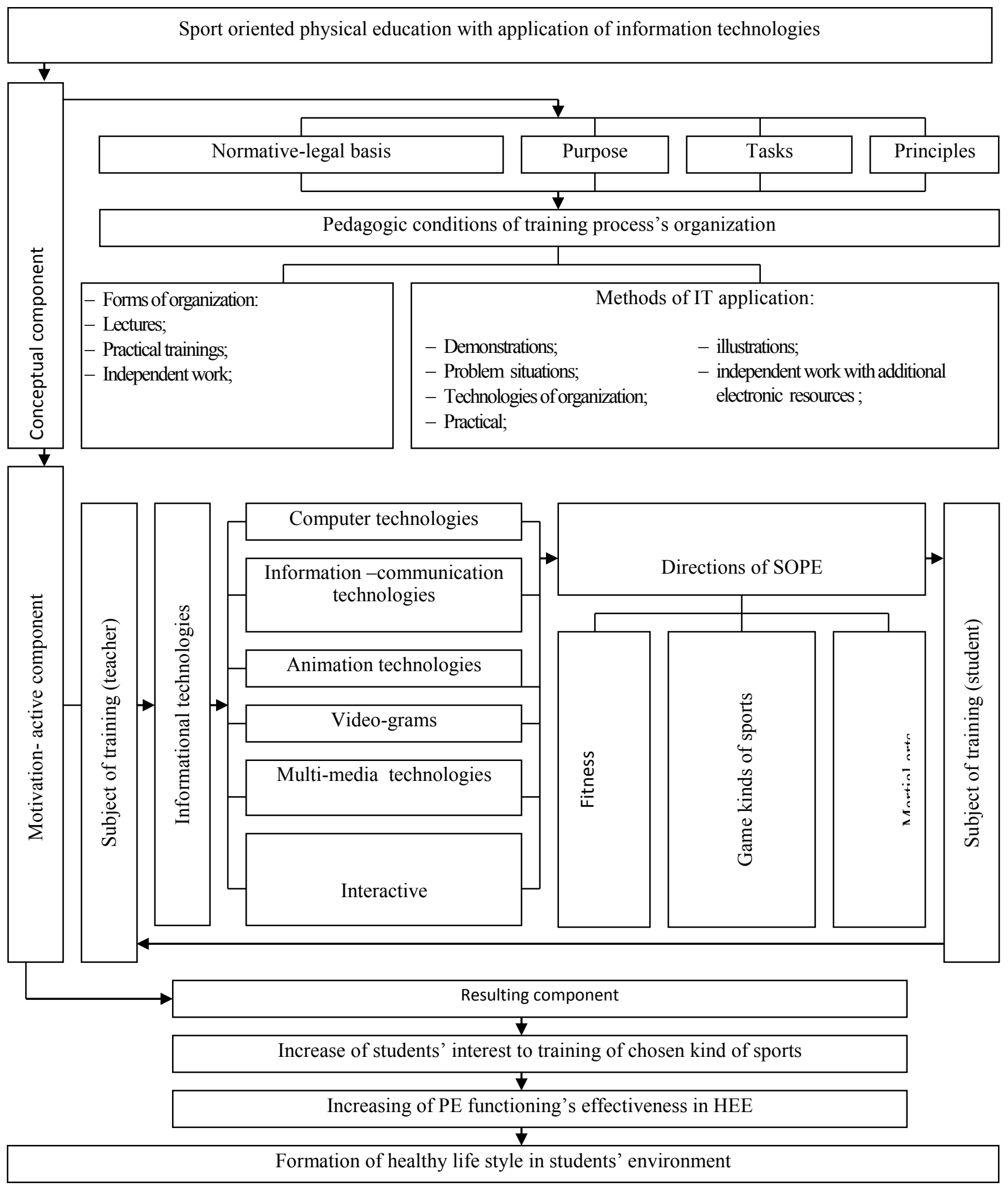

Fig.1. Structural model of SOPE with IT application 
- conceptual, determining purpose, tasks, principles of targeted orientations, pedagogic conditions of control over training process in SPE, realized through organizational forms and methods of IT application;

- motivation-active - determines orientation and educational interaction of IT by directions of SOPE for students' mastering of training program, realization of purpose and tasks;

- resulting - determines effectiveness of PR process in HEEs by detecting of involvement level and interest of trainees in regular physical culture and sport trainings; formation of healthy life style in students' environment.

For determination of authors' SOPE model with application of IT on students' physical fitness, level of motor skills and skills in chosen kind of sports in period from September 2013 to May 2014 we conducted forming pedagogic experiment on the base of KNU. Control $(\mathrm{CG}-\mathrm{n}=69)$ and experimental $(\mathrm{EG}-\mathrm{n}=68)$ groups included students, training in sport-oriented groups: basketball CG-1 $(n=14)$, EG-1 $(n=14)$ - boys, CG-2 $(n=10)$, EG-2 $(n=11)$ - girls; football in doors CG-3 (n=21), EG-3 (n=19) - boys; ping-pong CG-4 (n=12), EG-4 ( $\mathrm{n}=12)$ - boys, CG-5 (n=12), EG-5 ( $\mathrm{n}=12)-$ girls.

In CG we used IT of open type (accessible for all sites and blogs) in EG we used both IT of open type and closed type (video- and multimedia-technologies for training of motor actions, which stipulated application of animation videograms with accentuated demonstration of separate elements of technique; films on principles of theory and methodic of chosen kind of sports with real and animated heroes; published manuals with detail illustration of techniques' videograms; video-materials, worked out by groups of authors and video-materials from Internet). Application of open and closed types' IT in our researches was used for activation of students' conscious attitude to training process.

Experimental researches proved that application of SOPE with IT in KNU there was positive influence on increasing of the following:

- Physical fitness of EG trainees (EG $-\mathrm{p}<0.05-0.001)$;

- Students' mastering of motor skills in chosen kinds of sports and motor functioning (EG $-\mathrm{p}<0.05-0.001)$;

- Final mark of trainees on discipline "Physical education" (EG-1 - by 7.7 points, $p<0.01$; EG-2 - by 6.8 points $\mathrm{p}<0.01$; EG-3 - by 7.9 points, $\mathrm{p}<0.01$; EG- 4 - by 7.7 points, $\mathrm{p}<0.01$; EG- 5 -by 8.2 points, $\mathrm{p}<0.01$ ).

In $\mathrm{CG}$ there were no confident changes by the mentioned above indicators.

\section{Discussion}

According to the presented conceptual apparatus, with the help of methodic of collection and processing of information on operative level the final purpose of our research was formation of structural model SOPE with application of IT (see fig.1). On the base of the regarded concepts of models' construction and requirements [1, 2, 9-14, 16, 22] we chose approach, in foundation of which direct and full studying of training process in HEE was embedded.

The conducted analysis of PE departments' work showed that at modern stage there are several variants of PE organization in HEEs, the main of which can be presented in the form of two models. The first - is traditional organization of PE, where teachers' staff organizes trainings of rooted general developing content. The second - is transition model: from traditional PE to SOPE. In this model, groups of traditional PE function side-by side with sport-oriented PE groups on different kinds of sports and motor functioning. These groups are practically not connected with each other.

Both models of PE organization are imperfect. In first case we have students' restricted choice of training's content that reduces their motivation and effectiveness. The second variant is a step ahead in comparison with traditional PE organization. Actually it is an attempt of SOPE realization. But such approach also has a number of disadvantages. In it there is no single form of assessment and construction of program material. IT is used insufficiently in training process or is not used at all. Solution of this problem implies perfection of organization of both: organization and training process itself (training of movements in every kind of sports or motor functioning). It is facilitated by application of IT, implying usage with visual printing and dynamic video and multi-media aids.

For creation of SOPE structural model with IT application we used techniques, oriented on achievement of maximal correspondence between theoretical construction of model, purposefulness and possibility of its practical realization. It should be noted that positive side of such approach was the fact that foundation of each of these ideas [1, $11,13,19,20]$ in respect to perfection of training efficiency are certain changes. They consider urgent requirements of present time and motivation. Weak side of such approach is impossibility of $100 \%$ prognostication and objective preliminary assessment of the offered changes' after-effects. 


\section{Conclusions:}

Basing on conception of achievement of useful final result (formation of healthy life style in students' environment) and systemic analysis of training process in higher educational establishments [1-20] we formed structural model of sport-oriented students' physical education with the help of information technologies. We determined general characteristics and main structural components of the created model: conceptual, motivation-active and resulting.

Experimental researches confidently proved purposefulness of SOPE model's application with usage of IT for achievement of useful final result of training in PE system in higher school - creation of necessary for formation of healthy life style in students' environment and cultivation of graduate's demand in physical (motor) functioning in further everyday life.

In the future we shall orient our researches on experimental determination of effectiveness of SOPE model's with IT application functioning.

\section{Acknowledgement}

The research has been conducted in compliance with combined plan of scientific-research works in sphere of physical culture and sports for 2013-2014 by topic "Theoretical-methodic principles of application of information, pedagogic and medical-biological technologies for formation of healthy life style" (State registration number 0113U002003)

\section{Conflict of interests}

The authors declare that there is no conflict of interests.

\section{References:}

1. Bal'sevich VK, Lubysheva LI. Sportivno orientirovannoe fizicheskoe vospitanie: obrazovatel'nyj i social'nyj aspekty [Sport-oriented physical education: educational and social aspects]. Teoriia i praktika fizicheskoj kul'tury 2003;5:1922. (in Russian)

2. Iermakov SS, Ivashchenko SN, Guzov VV. Osobennosti motivacii studentov s primeneniem individual'nykh programm fizicheskoj samopodgotovki [Specificities of students' motivation with application of individual programs of physical self-training]. Physical education of students 2012;4:59-61. (in Russian)

3. Iermakov SS Issledovaniia v sporte: analiz informacii v seti Internet Ukrainy, Rossii i respubliki Belarus' [Researches in sports: analysis of information in Internet of Ukraine, Russia, Belarus]. Pedagogics, psychology, medicalbiological problems of physical training and sports 2001;18:51-58. (in Russian)

4. Iermakov S. Osnovy sozdaniia informacionnoj sistemy obespecheniia nauchnykh issledovanij v kontekste edinogo obrazovatel'nogo prostranstva [Principles of creation of informational system for ensuring of scientific researches in context of single educational space]. Nauka v olimpijskom sporte 2005;2:117-127. (in Russian)

5. Iermakov SS, Krivencova IV. Perspektivi rozvitku navchal'noi disciplini «Fizichne vikhovannia» $u$ vishchikh navchal'nikh zakladakh Ukraini [Prospects of development of discipline "Physical education" in higher educational establishments of Ukraine]. Pedagogika ta psikhologiia 2015;47:117-124. (in Ukrainian)

6. Zolochevs'kij VV. Teoriia i praktika organizacii fizkul'turno-masovoi roboti iz students'koiu moloddiu u vitchiznianij pedagogici. Cand. Diss. [Theory and practice of organization of mass physical culture work with students in domestic pedagogic. Cand. Diss.]. Kharkiv; 2009. (in Ukrainian)

7. Kamaev OI, Kamaeva EK. Osobennosti ispol'zovaniia kompetentnostnogo podkhoda v zdorov'eformiruiushchikh tekhnologiiakh v usloviiakh vuza [Specificities of usage of competence approach to health-formation technologies in HEE conditions]. Physical education of students 2010;6:37 - 39. (in Russian)

8. Kashuba VA, Valikov DP, Sergienko KN. Komp'iuternye tekhnologii v sisteme vysshego fizkul'turnogo obrazovaniia [Computer technologies in system of higher physical culture education]. Fiziceskoe vospitanie studentov tvorceskih special'nostej 2002;6:22-27. (in Russian)

9. Kashuba VA, Futornyj SM, Golovanova NL. K voprosu ispol'zovaniia informacionnykh tekhnologij v processe fizicheskogo vospitaniia studencheskoj molodezhi [On usage of informational technologies in process of students' physical education]. Slobozhans'kij naukovo-sportivnij visnik 2011;4:157-163. (in Russian)

10. Kolos NA. Sovremennye informacionnye tekhnologii v fizicheskom vospitanii detej, podrostkov i studencheskoj molodezhi [Modern information technologies in physical education of children, adolescents and students], Lutsk: Teren; 2011. (in Russian) 
11. Krivcova MA. Interaktivnye metody obucheniia fizicheskoj kul'ture pri podgotovke specialista [Interactive methods of physical culture training in preparation of specialist]. Trudy SPbGUKI 2013;1:460-462. (in Russian)

12. Krucevich TIu, Nesterenko AN. Motivacionnye prioritety zdorovogo obraza zhizni studentok vuzov [Motivation priorities of healthy life style of HEEs' girl students]. In: IX Mizhnarodnij naukovij kongress "Olimpijs'kij sport $i$ sport dlia vsikh», 20-23 veresnia, 2005, Kiiv [IX International scientific congress "Olympic sports and sports for all” 2005, September 20-23, Kyiv], Kiev; 2005. p. 581. (in Russian)

13. Kuz'min VA, Kudriavcev MD, Kopylov IuA, Galimov GIa, Strel'nikov VA. Konceptual'nye osnovy neobkhodimosti obnovleniia dopolnitel'nogo ozdorovitel'nogo fizicheskogo vospitaniia studentov [Conceptual principles of demand in additional health related physical education of students]. In: Mezhdunarodnaia nauchno-prakticheskaia konferenciia. 8-10 aprelia, 2014, Minsk [International scientific-practical conference. April 8-10, 2014. Minsk] Minsk: BGUFK; 2014. p. 162-165. (in Russian)

14. Liu Iun Cian'. Motivaciia fizkul'turno-sportivnoj aktivnosti studencheskoj molodezhi v sisteme formirovaniia ustanovki na zdorovyj obraz zhizni. Cand. Diss. [Motivation of physical culture - sport functioning of students in system of formation of orientation for healthy life style. Cand. Diss.], Minsk; 2011. (in Russian)

15. Moskalenko N. Pedagogichni innovacii u fizichnomu vikhovanni [Pedagogic innovations in physical education]. Sportivnij visnik Pridniprov'ia 2009;1:19-22. (in Ukrainian)

16. Ol'khovij OM. Stan funkcionuvannia sistemi fizichnogo vikhovannia zakladiv vishchoi osviti [Functioning of physical education system in higher educational establishments]. Teoriia $i$ metodika fizichnogo vikhovannia $i$ sportu 2014; 2:79 - 83 (in Ukrainian)

17. Poproshaev AV, Muntian VS. Preimushchestva sekcionnoj formy organizacii uchebnogo processa po discipline «fizicheskoe vospitanie» [Advantages of organization of circles' form of "physical education" discipline's training]. Physical education of students 2011;4:67-70. (in Russian)

18. Radaeva SV. Fizicheskoe vospitanie studentov nefizkul'turnogo vuza na osnove sportivno-orientirovannykh tekhnologij. Cand. Diss. [Physical education of students of not physical culture HEE on the base of sport-oriented technologies. Cand. Diss]; 2008. (in Russian)

19. Savin SV, Stepanova ON. Konceptual'nye i prikladnye aspekty tekhnologizacii proektirovochnoj deiatel'nosti v sfere ozdorovitel'noj fizicheskoj kul'tury [Conceptual and applied aspects of technologies' implementation in projecting functioning in sphere of health related physical culture]. Podgotovka pedagoga po fizicheskoj kul'ture v usloviiakh modernizacii Rossijskogo obrazovaniia [Training of pedagogue of physical culture in conditions of modernization of Russian education], Moscow, MGPU; 2007. p. 149-156. (in Russian)

20. Sadovnikova VV. Ispol'zovanie valeologicheskogo podkhoda v vuze dlia formirovaniia orientacij studencheskoj molodezhi [Application of valuelogic approach for formation of students' orientations in HEE]. Aktual'nye problemy fizicheskoj reabilitacii i ergoterapii [Urgent problems of physical rehabilitation and ergo-therapy], Minsk: BGUFK; 2008. p. 97-100. (in Russian)

21. Temchenko VO. Sportivno-oriientovane fizichne vikhovannia u vishchikh navchal'nikh zakladakh iz zastosuvanniam informacijnikh tekhnologij. Cand. Diss. [Sport-oriented physical education in higher educational establishments with application of information technologies. Cand. Diss.], Dnipropetrovsk; 2015. (in Ukrainian)

22. Futornyj S, Karavatskaia M. Informacionnye tekhnologii i Internet-resursy v formirovanii zdorovogo obraza zhizni studentov v processe fizicheskogo vospitaniia [Information technologies and Internet resources in formation of students' healthy life style in process of physical education]. Molodizhnij naukovij visnik Skhidnoievropejs'kogo nacional'nogo universitetu 2013;9:68-73. (in Russian)

23. Futornyi S. Actual issues of improving the process of student's physical education through the application of modern health-saving technologies. Molodizhnij naukovij visnik Skhidnoievropejs'kogo nacional'nogo universitetu 2014;14:26-30.

24. Abar B. Promoting tobacco cessation utilizing pre-health professional students as research associates in the emergency department. Addictive Behaviors 2015;40;73-76.

25. Al-Hariri MT, Al-Hattami AA. Utilization of internet by health colleges students at the University of Dammam. Journal of Taibah University Medical Sciences 2015;10(1):66-73. 
26. Belykh SI. Methodological foundations of individually oriented approaches to ground of physical education unprofessional university students. Physical education of students 2013;3:11-17. http://dx.doi.org/10.6084/m9.figshare.669662

27. Belykh SI. Structure of the concept of personality oriented physical education university students. Physical education of students, 2013;4:3-9. http://dx.doi.org/10.6084/m9.figshare.669663

28. Berger H, Franke GH, Hofmann F-H, Sperth M, Holm-Hadulla RM. Mental health of students and its development between 1994 and 2012. Mental Health \& Prevention. 2015;3(1-2):48-56.

29. Dolan E, Hancock E, Wareing A. An evaluation of online learning to teach practical competencies in undergraduate health science students. The Internet and Higher Education 2015;24(0):21-5.

30. Hadden KB. Health literacy training for health professions students. Patient Education and Counseling 2015;98(7):918-20.

31. Holm-Hadulla RM, Koutsoukou-Argyraki A. Mental health of students in a globalized world: Prevalence of complaints and disorders, methods and effectivity of counseling, structure of mental health services for students. Mental Health \& Prevention. 2015;3(1-2):1-4.

32. Iermakova TS. Peculiarities of forming health culture of pupils in Poland: historical aspect. Pedagogics, psychology, medical-biological problems of physical training and sports 2014;6:16-20. http://dx.doi.org/10.6084/m9.figshare. 1004090

33. Kovaleva MV, Rumba OG. Active games in physical education students of special medical group with limited capacity of cardiovascular system. Physical education of students 2013;4:35-45. http://dx.doi.org/10.6084/m9.figshare.681644

34. Kramida IE. Exercises for students of different medical groups as factors of the weakening bad habits at students. Physical education of students 2013;4:46-50. http://dx.doi.org/10.6084/m9.figshare.669680

35. Lapkin S, Levett-Jones T, Gilligan C. Using the Theory of Planned Behaviour to examine health professional students' behavioural intentions in relation to medication safety and collaborative practice. Nurse Education Today. 2015;35(8):935-40.

36. Malenyuk TV, Kosivska AV. Training at sport circle as priority form of organization of students' physical education (on example of shaping). Pedagogics, psychology, medical-biological problems of physical training and sports 2015;4:38-42. http://dx.doi.org/10.15561/18189172.2015.0407

37. Michael Chia, Marcus Lee. Relationship between quality of life and resilience among sport-active Singaporean youth. Physical education of students 2015;2:29-36. http://dx.doi.org/10.15561/20755279.2015.0205

38. Mytskan BM, Fedynyak NV. Justification revitalizing body of persons third age by means of physical education. Pedagogics, psychology, medical-biological problems of physical training and sports 2014;10;18-23. http://dx.doi.org/10.5281/zenodo.10485

39. Pichurin VV. Psychological and psycho-physical training as a factor of personal anxiety at students. Pedagogics, psychology, medical-biological problems of physical training and sports 2015;3:46-51. http://dx.doi.org/10.15561/18189172.2015.0307

40. Pidpomoga AY. Dynamic of functional indicators' changes of students having harmful habits (on example of smoking) under influence of organized motion functioning. Physical education of students 2015;2:22-28. http://dx.doi.org/10.15561/20755279.2015.0204

41. Prusik Krzysztof, Prusik Katarzyna, Kozina ZhL, Iermakov SS. Features of physical development, physical preparedness and functional state of boys and girls - students of Polish higher educational establishments. Physical education of students 2013;1:54-61. http://dx.doi.org/10.6084/m9.figshare.96415

42. Roters TT. Physical improvement of students during interactive physical and aesthetic education. Physical education of students 2013;4:72-76. http://dx.doi.org/10.6084/m9.figshare.663624

43. Siri A, Rui M. Distance Education for Health Professions' Students. Procedia - Social and Behavioral Sciences. 2015;174(0):730-8.

44. Usher K, Woods C, Casella E, Glass N, Wilson R, Mayner L, et al. Australian health professions student use of social media. Collegian. 2014;21(2):95-101. 
45. Yermakova TS. Individualization of forming health culture in schoolchildren of Polish schools. Pedagogics, psychology, medical-biological problems of physical training and sports 2015;1:29-33. http://dx.doi.org/10.15561/18189172.2015.0106

46. Zaporozhanov VA, Boraczynski Tomasz. Discussion on the concepts of "coordination" and "agility" in terms of physical education. Pedagogics, psychology, medical-biological problems of physical training and sports 2015;3:15-19. http://dx.doi.org/10.15561/18189172.2015.0303

47. Zaporozhanov VA. About reliable indicator of proprioception in agility control. Pedagogics, psychology, medicalbiological problems of physical training and sports 2013;4:21-25. http://dx.doi.org/10.6084/m9.figshare.693023

48. Zaporozhanov VA, Borachinski T. On the transfer of skills skill in different conditions of motor activity. Pedagogics, psychology, medical-biological problems of physical training and sports 2013;9:25-28. http://dx.doi.org/10.6084/m9.figshare.749693

49. Zaporozhanov VA, Boraczynski T. Evaluation improvement of coordination abilities in physically active persons. Pedagogics, psychology, medical-biological problems of physical training and sports 2009;9:52 - 55. 


\section{Information about the authors:}

Olkhovy O.M.: http://orcid.org/0000-0002-5223-5229; skZirka@email.ua; Kharkov National University; Liberty pl. 4, Kharkov, 61077, Ukraine.

Petrenko Y.M.: $\quad$ http://orcid.org/0000-0001-8169-8807; sport@karazin.ua; Kharkov National University ; Liberty pl. 4, Kharkov, 61077, Ukraine.

Temchenko V.A.: http://orcid.org/0000-0003-0171-4614; temchenko1961@mail.ru; Kharkov National University; Liberty pl. 4, Kharkov, 61077, Ukraine.

Timchenko A.N.: http://orcid.org/0000-0001-7745-0817; Anch555@rambler.ru; Kharkov National University; Liberty pl. 4, Kharkov, 61077, Ukraine.

Cite this article as: Olkhovy O.M., Petrenko Y.M., Temchenko V.A., Timchenko A.N. Model of students' sportoriented physical education with application of information technologies. Physical education of students 2015;3:29-37. http://dx.doi.org/10.15561/20755279.2015.0304

The electronic version of this article is the complete one and can be found online at: http://www.sportpedu.org.ua/html/arhive-e.html

This is an Open Access article distributed under the terms of the Creative Commons Attribution License, which permits unrestricted use, distribution, and reproduction in any medium, provided the original work is properly cited (http://creativecommons.org/licenses/by/3.0/deed.en).

Received: 18.06 .2015

Accepted: 29.06.2015; Published: 30.06.2015 